\title{
The Effectiveness of China's Foreign Trade Liberalization
}

\begin{abstract}
This paper studies the ex-post trade effects of China's multilateral, regional and bilateral trade liberalization using augmented gravity and panel data estimation methods for the period 1995-2016. China's accession to the WTO was revealed to have had a significant impact on the volume of trade as well as on bilateral exports and imports. Regional trade agreements and the majority of bilateral trade agreements were found not to be effective in increasing China's foreign trade. Only the agreements with Chile, Costa Rica and Switzerland were effective in increasing China's trade volume. Moreover, the results for Chile were driven by increases in both exports and imports, while for Costa Rica and Switzerland only by increased imports from these countries.
\end{abstract}

Keywords

China $\bullet$ trade liberalization $\bullet$ incomplete specialization $\bullet$ gravity model $\bullet$ WTO

(C) University of Warsaw - Faculty of Geography and Regional Studies

\author{
Andrzej Cieślik $\mathbb{C}$, \\ Tenzin Tseyang \\ Faculty of Economic Sciences, University of Warsaw, \\ Warsaw, Poland \\ e-mail: cieslik@wne.uw.edu.p \\ e-mail: tenzintseyang0@gmail.com \\ Received: 25 January 2020 \\ Accepted: 11 May 2021
}

Introduction

The People's Republic of China (PRC) is a giant country that has been experiencing rapid economic growth for the last thirty years. Currently, it is the second largest economy in the world after the US and the largest exporter, responsible for about 15\% of total global trade. The PRC has often been regarded as one of the leading players in the world economy and the dominant trading power in East Asia. Given the size of the country, the pace of economic development, and its outward and market orientation, China's economy and its trade policies exert a growing influence on the global trading system. Many developing countries strive to emulate successful economic strategies for their economic development and the PRC is often seen as a good example to follow.

China's rapid economic growth has frequently been attributed to its successful trade liberalization and market-oriented policies. Its integration into global economic activities began in 2001 with accession to the World Trade Organization (WTO), followed by various economic engagements in the form of several bilateral and regional trade agreements with a range of provisions (Song \& Cieślik 2020). The empirical evidence on the determinants of China's trade flows, although already quite extensive, focuses mostly on the effects of particular trade agreements, or on the trading partner's economy. At the same time, the number of empirical studies on the effects of trade liberalization on China's foreign trade is still fairly limited. Therefore, the main goal of this paper is to study empirically the ex-post effects of preferential trade liberalization from China's perspective.

In the theoretical literature there are divergent views on the reasons for concluding preferential trade agreements and their effects (Bagwell \& Staiger 1998), Bhagwati et al. (1998), Ethier (1998), Panagariya (2000), Rivera-Batiz \& Oliva (2003). It has often been argued that unilateral accession to a pre-existing multilateral agreement allows governments of acceding countries to free themselves from the pressure of organized interest groups whose efforts to protect their own interests can be reflected in high tariffs (Grossman \& Helpman 1994; 1995). For this reason, it can be hypothesized that institutionalized trade liberalization within the framework of preexisting agreements should be more effective because it should be more immune to political pressure from various organized interest groups than when negotiating new bilateral or regional agreements. This is due to the fact that the attitude of existing international organizations, such as the WTO, is not flexible for candidate countries and is often manifested in 'take-it-or-leave-it' offers, where the possibilities for negotiating and obtaining various concessions are very limited (Cieślik 2007). At the same time, in the case of new bilateral or multilateral agreements, where there is no institutionalized external pressure on far-reaching trade liberalization, it is difficult to determine the link between the type of concluded agreement and its impact on the volume of trade. On the one hand, it can be argued that the effectiveness of bilateral agreements should be greater than multilateral agreements, as fewer participants should hopefully mean fewer contentious issues and deeper trade integration (Ethier 1998). On the other hand, the effectiveness of trade agreements may depend on the actual strength, and degree of organization of entrepreneurs in the lobbying groups in particular countries.

Insights from the theoretical literature allow us to formulate the main research hypothesis which states that an effective 
form of trade liberalization is institutionalized liberalization in the form of unilateral accession to a pre-existing international organization, while new bilateral and regional agreements may not necessarily result in increased trade. As the theory does not provide clear indications with respect to the effectiveness of various preferential trade agreements, the assessment of their effects remains an empirical task. Therefore, in this paper we validate empirically whether China's WTO accession positively contributed to trade expansion and compare its effectiveness against the effectiveness of regional and bilateral trade liberalization. In particular, in this paper we identify those trade agreements that turned out to be effective in raising China's bilateral trade volume.

The structure of the paper is as follows. The next section provides a review of previous studies on China's trade liberalization. Next, the research methodology and statistical data are discussed. Finally, the empirical results are reported. The last section summarizes and concludes with policy recommendations and guidelines for future research.

\section{Literature review}

The empirical assessment of the effects of preferential trade agreements on trading volumes between participating countries has been the subject of intensive research by economists for over 40 years. However, empirical studies into the impact of various agreements aimed at liberalizing trade on trade volumes continue to stir up a great deal of controversy among researchers. For example, in one of the most frequently cited studies on the effectiveness of WTO accession, Rose (2004) found no significant effect of WTO accession on trade between WTO members. In contrast, Tomz et al. (2007) showed that WTO participation substantially increased trade, while Subramanian and Wei (2007) demonstrated that, although WTO membership increased trade between members, the magnitude of the effect was uneven between the trading economies. In particular, their results indicated an asymmetry between the effects on imports for industrialized and developing countries that might be due to fact that the developing countries were exempted from reducing their import barriers.

The effects of preferential trade liberalization for Asian economies were studied by Ekanayake et al. (2010). They estimated an ad hoc gravity model using data for 19 Asian countries, including China, for the period 1980 to 2009. They found that ASEAN, the Bangkok Agreement and SAARC had a positive effect on trade expansion. Subsequently, Cieślik and Song (2012) studied the impact of ASEAN on the bilateral trade of its member countries from 1967 to 2008. They found that, on average, ASEAN significantly increased the bilateral trade of member countries. However, their results were country-specific and indicated that ASEAN benefitted only large economies with a long history of membership, while smaller and newer members did not benefit from trade expansion. More recently, the effects of regionalism on trade in South Asia were studied by Dembatapitiya and Weerahewa (2015) using the simple gravity model and cross section data. They found that RTAs and WTO membership had significant effects on South Asian exports.

In the context of China, ex-ante trade gains from China's WTO membership were evaluated by lanchovichina and Martin (2004), who found a positive and significant effect of China's accession to the WTO using a computable general equilibrium (CGE) model. Subsequently, Park et al. (2008) employed a CGE model to study the ex-ante effects of establishing a free trade area between ASEAN and China (ACFTA). Their results showed that ACFTA would increase their bilateral trade by more than $33 \%$. The exante effects of ACFTA on member countries' trade flows were also studied by Sheng et al. (2012) who used the gravity model to show that a free trade agreement between ASEAN and the PRC would lead to substantially higher bilateral trade. The gravity model was also used by Bhattacharya and Bhattacharyay (2007) to analyze the exante effects of a potential India-China trade cooperation in the form of a preferential trade agreement. Their results indicated that such an agreement could have a positive effect on bilateral trade volumes.

At the same time, China's approach to the design of regional and bilateral trade agreements has received a lot of attention in the literature on international politics (Antkiewicz \& Whalley 2011; Li, Wang, \& Whalley 2017; Song \& Yuan 2012; Zeng 2010, 2016; Sampson, 2021). The consensus that emerges from this literature is that the majority of these agreements were of low quality in terms of coverage and liberalization because they were driven largely by political, not economic, considerations (Antkiewicz \& Whalley 2011; Kwei 2013; Zeng 2016). Each of these agreements incorporated specific Chinese preferences in terms of design and, crucially, because of the low quality of the initial agreement, they entail substantial later expansion in terms of both coverage and liberalization (Antkiewicz \& Whalley 2011; Ravenhill 2010; Zeng 2010).

Yet whilst the political and strategic implications of these agreements have received particular attention, surprisingly little attention has been paid to the ex-post evaluation of their economic effects. Therefore, it is necessary to complement the previous studies with ex-post evaluation of the trade effects of these agreements. Moreover, previous empirical studies focus mainly on the effects of China's WTO accession while relatively little attention is devoted to the ex-post evaluation of the effectiveness of particular Chinese bilateral and regional trade agreements. Therefore, in this paper we study and compare the ex-post effects of China's multilateral, regional and bilateral trade liberalization.

\section{Methodology and data}

The empirical gravity equation is one of the most popular analytical tools used to study the effectiveness of preferential trade liberalization and common currency adoption. However, previous studies very often used ad hoc gravity equations that had no microeconomic foundations. Instead they relied on a simple analogy with physics that mimics gravitational interaction as described in Isaac Newton's universal law of gravity. In its most basic form, the gravity equation predicts that bilateral trade flows are positively related to the economic sizes of the trading partners and negatively related to the distance between them (Cieślik 2007). In contrast to these studies, we use the structural gravity equation that can be directly derived from formal theoretical models which assume incomplete specialization in production and control for differences in relative factor endowments between trading partners. ${ }^{1}$

The relationships between trade and independent variables derived from the theory are estimated using the standard techniques of panel data econometrics including fixed and random effects estimators. The appropriateness of controlling for country-specific effects is tested using the F-test and LM-test for the fixed and random effects, respectively. Subsequently, the Hausman test is used to determine the proper estimation format. For the sake of comparison with earlier studies, we also include the simple OLS results. The estimated equation in generalized form is expressed in logarithmic form as follows: ${ }^{2}$

${ }^{1}$ For technical derivations of the structural gravity equation from the formal theoretical models of monopolistic competition see Cieślik (2009; 2015). The examples of empirical studies based on this approach include Cieślik and Hagemejer $(2009 ; 2011)$, Cieślik et al. (2009; 2012; 2014), Devadason (2015), Devadason et al. (2014; 2017), Devadason and Mubarik (2021) although not in the context of China's trade.

${ }^{2}$ We choose to estimate the model in logarithmic form in order to interpret the estimated coefficients as elasticities. 
$\ln \left(\right.$ Trade $\left._{i j t}\right)=\beta_{0}+\beta_{1} \ln \left(G D P_{i t}+G D P_{j t}\right)+\beta_{2} \ln \left(1-s_{i t}{ }^{2}-s_{j t}{ }^{2}\right)+\beta_{3} \ln \left(K_{i t} / L_{i t}+K_{j t} /\right.$ $\left.L_{j t}\right)+\beta_{4} \ln \left(\left|K_{i t} / L_{i t}-K_{j t} / L_{j t}\right|\right)+\beta_{5} \ln \left(T_{i t} / L_{i t}+T_{j t} / L_{j t}\right)+\beta_{6} \ln \left(\left|T_{i t} / L_{i t}-T_{j t} / L_{j t}\right|\right)+$ $\beta_{7} \ln \left(\right.$ Distance $\left._{i j}\right)+\beta_{8}$ WTO $_{j t}+\sum_{n=1}^{N} \beta_{n i j} R T A_{i j t}+v_{i j}+u_{t}+\epsilon_{i j t}$

where: Trade $_{\text {iit }}$ is bilateral trade flow between country $i$ in country $j$ in year $t, \mathrm{GDP}_{\mathrm{it}}$ and $\mathrm{GDP}_{\mathrm{jt}}$ are the GDPs of country $\mathrm{i}$ and country $j$ respectively in year $t, s_{i t}$ and $s_{j t}$ are the shares of country i's GDP and country $j$ 's GDP respectively in their combined GDP in year $t, \mathrm{~K}_{\mathrm{it}} / \mathrm{L}_{\mathrm{it}}$ and $\mathrm{K}_{\mathrm{jt}} / \mathrm{L}_{\mathrm{jt}}$ are the ratios of physical capital to workers in country $i$ and country $j$ respectively in year $t, T_{i t} / L_{i t}$ and $T_{j t} / L_{j t}$ are the ratios of arable land per worker in country $i$ and country $j$ respectively in year $t$, DISTANCE ${ }_{i j}$ is a variable measuring the geographical distance between the capitals of country $i$ and country j, $\mathrm{WTO}_{\text {it }}$ is an indicator variable for the WTO membership of country $i$ in year $t, R_{A} A_{i t}$ is an indicator variable for the existence of a regional trade agreement between countries $i$ and $j$ in year $t, v_{i j}$ is the individual country-pair specific effect that may be fixed or random, $u_{t}$ is the individual time specific effect, while $\varepsilon_{\mathrm{ijt}}$ is the error term, for $\mathrm{i}=$ China, $\mathrm{j}=1, \ldots, 175$ trade partners of China, $\mathrm{t}$ $=1995, \ldots, 2016$, and B's are the parameters to be estimated.

The statistical data used in this study covers China and its 175 trading partners over the period 1995 to 2016 . The sample choice is determined by the availability of data. Data sources include COMTRADE, the World Bank, CEPII and Penn World Table.

The dependent variable representing China's bilateral trade includes total trade volume, exports and imports. Trade data is culled from the COMTRADE database and is scaled into 2010 constant prices in billions of US dollars (USD) and used in log form for the OLS and panel data estimations. The estimation is done initially for total trade, representing the sum of exports and imports between China and its partners, while later estimations are done separately for exports and imports, to account for the more detailed effects of trade liberalization.

The absolute income of trading partners is represented by the sum of their GDPs, while relative income, represented by their income similarity, is calculated using GDP values taken from the World Development Indicators of the World Bank in billions of USD. GDP is expressed in constant 2010 US dollars and evaluated in PPP to allow for comparability across countries. The relative factor endowment variables are expressed as the sums of and differences in $\mathrm{K} / \mathrm{L}$ ratios and $\mathrm{T} / \mathrm{L}$ ratios between China and the partner country in a given year. Data for arable land $(\mathrm{T})$ and labour $(\mathrm{L})$ are collected from the World Development Indicators of the World Bank, while data for capital $(K)$ are obtained from the Penn World Table, Version 9. Distance data is taken from CEPII and is the distance between the capital city of China, Beijing, and the capital cities of its trading partners expressed in kilometers.

China's accession to the WTO is represented by a dummy variable that takes the value zero for the period 1995-2000 and 1 otherwise. Regional trade agreements that were notified to the WTO and were in force during the sample period are represented by a set of dummy variables which take the value of 1 if both China and its partners belong to the RTA at time period $\mathrm{t}$, and zero otherwise. ${ }^{3}$ Currently, China has implemented 16 regional and bilateral trade agreements with both developed and developing nations. These include free trade agreements with its own territories (?) such as Macao and Hong Kong (CEPA), South East Asian countries (ASEAN), Asia-Pacific countries (APTA), South American countries (Chile, Peru, Costa Rica), Oceanic countries (Australia, New Zealand), West Asian countries (Georgia, Pakistan), a South Asian country (Maldives) and West

${ }^{3}$ The RTA with Singapore in 2009 is excluded as it is already in an RTA with China as a member of ASEAN.
European countries (Iceland, Switzerland). ${ }^{4}$ By implementing these agreements China has lowered trade barriers and therefore they are expected to increase China's trade flows.

\section{Estimation results}

In this section we present and discuss our estimation results. First, in Table 1, we report the estimation results obtained for volume of trade. Then, in Table 2, we report the estimation results obtained for exports and, in Table 3, for imports.

The baseline OLS estimation results for volume of trade are reported in column (1) of Table 1. These results show that the estimated parameters on the WTO indicator variable and all free trade agreements except the one with Macao are highly statistically significant. In particular, the positive signs of the estimated parameters on China's WTO accession and the agreements with Hong Kong, ASEAN, Chile, New Zealand, Peru, Costa Rica and Switzerland suggest that these agreements do positively affect China's bilateral trade. At the same time, the estimated parameters on trade agreements with APTA, Pakistan and Iceland display negative signs.

In column (2) we study the robustness of the OLS results using the fixed effects estimator. ${ }^{5}$ The F-test with $p$-value equal to zero does not rule out the joint significance of individual, countryspecific, fixed effects. The estimation results obtained using the fixed effects show that China's accession to the WTO and trade agreements with APTA, Pakistan and Peru lose their previous statistical significance. The agreements with Hong Kong, New Zealand and ASEAN remain significant but, in contrast to the OLS results, the estimated coefficients now display negative signs. The magnitudes of the estimated coefficients for Costa Rica and Switzerland are reduced but remain statistically significant and positive. The trade agreement with Macao now becomes significant but displays a negative sign.

In column (3), we show the estimation results obtained via the random effects estimator. The LM test with p-value equal to zero shows the appropriateness of controlling for individual country-specific random effects. These results show that China's accessions into the WTO and the free trade agreements with Chile, Switzerland and Costa Rica are positively related to China's trade volume. At the same time, the estimated parameters on the trade agreements with APTA, Hong Kong, Macao, ASEAN, Pakistan, New Zealand and Iceland are significant and display negative signs. The Hausman test with $p$-value equal to 0.670 identifies the random effects as the proper estimation format.

The estimation results obtained via the fixed effects estimator with individual time effects for specific years of the sample are shown in column (4). These results are quite similar to the results obtained using the fixed effects estimator without the individual time effects reported in column (2). In particular, these results indicate that the WTO variable is highly significant and displays a positive sign. Positive and statistically significant coefficients are reported also for the trade agreements with Costa Rica and Switzerland. At the same time, the estimated parameters for the trade agreements with APTA, ASEAN, Hong Kong, Macao, Pakistan, New Zealand, and Iceland display negative signs and are statistically significant.

Finally, in column (5), we report the estimation results obtained using the random effect estimator with time effects. These results are similar to the results obtained using the random effects estimator without the individual time effects reported in column (3). In particular, these results show that China's accession to the WTO and the free trade agreements with Chile,

${ }^{4}$ Due to data constraints, we are not studying the effects of two recent agreements with small countries: Georgia and Maldives.

${ }^{5}$ The indicator variable for the trade agreement with Chile and geographic distance were dropped due to their colinearity with the fixed effects. 
Table 1. Dependent Variable: Trade Volume

\begin{tabular}{|c|c|c|c|c|c|}
\hline Explanatory variable & $\begin{array}{l}\text { OLS } \\
\text { (1) }\end{array}$ & $\begin{array}{l}F E \\
\text { (2) }\end{array}$ & $\begin{array}{l}R E \\
\text { (3) }\end{array}$ & $\begin{array}{c}F E(\text { year) } \\
\text { (4) }\end{array}$ & $\begin{array}{c}R E \text { (year) } \\
\text { (5) }\end{array}$ \\
\hline Total GDP & $\begin{array}{c}2.317^{* \star *} \\
(0.058)\end{array}$ & $\begin{array}{c}2.233^{\star * *} \\
(0.224)\end{array}$ & $\begin{array}{c}2.285^{\star \star \star} \\
(0.222)\end{array}$ & $\begin{array}{c}1.917^{* * *} \\
(0.126)\end{array}$ & $\begin{array}{c}1.939^{* * *} \\
(0.122)\end{array}$ \\
\hline Similarity index & $\begin{array}{c}0.970^{* * *} \\
(0.014)\end{array}$ & $\begin{array}{c}0.784^{* * *} \\
(0.091)\end{array}$ & $\begin{array}{c}0.858^{* * *} \\
(0.063)\end{array}$ & $\begin{array}{c}0.821^{* * *} \\
(0.081)\end{array}$ & $\begin{array}{c}0.908^{* \star *} \\
(0.058)\end{array}$ \\
\hline Sum of $K / L$ ratio & $\begin{array}{c}0.177^{* \star \star} \\
(0.045)\end{array}$ & $\begin{array}{c}0.150 \\
(0.184)\end{array}$ & $\begin{array}{c}0.270 \\
(0.179)\end{array}$ & $\begin{array}{l}-0.166 \\
(0.149)\end{array}$ & $\begin{array}{l}-0.024 \\
(0.135)\end{array}$ \\
\hline Difference of $K / L$ ratio & $\begin{array}{c}0.070^{* * *} \\
(0.023)\end{array}$ & $\begin{array}{l}-0.020 \\
(0.037)\end{array}$ & $\begin{array}{l}-0.010 \\
(0.038)\end{array}$ & $\begin{array}{c}0.009 \\
(0.035)\end{array}$ & $\begin{array}{c}0.017 \\
(0.035)\end{array}$ \\
\hline Sum of $T / L$ ratio & $\begin{array}{c}-0.276^{* * *} \\
(0.052)\end{array}$ & $\begin{array}{l}-1.075^{\star} \\
(0.572)\end{array}$ & $\begin{array}{l}-0.328 \\
(0.213)\end{array}$ & $\begin{array}{l}-0.814 \\
(0.558)\end{array}$ & $\begin{array}{l}-0.269 \\
(0.211)\end{array}$ \\
\hline Difference of $T / L$ ratio & $\begin{array}{c}0.259^{* * *} \\
(0.032)\end{array}$ & $\begin{array}{c}0.165 \\
(0.137)\end{array}$ & $\begin{array}{c}0.148 \\
(0.115)\end{array}$ & $\begin{array}{c}0.153 \\
(0.131)\end{array}$ & $\begin{array}{c}0.142 \\
(0.112)\end{array}$ \\
\hline Distance & $\begin{array}{c}-0.553^{* * *} \\
(0.056)\end{array}$ & (omitted) & $\begin{array}{c}-0.722^{* * *} \\
(0.216)\end{array}$ & (omitted) & $\begin{array}{c}-0.795^{\star * *} \\
(0.209)\end{array}$ \\
\hline RTA-APTA & $\begin{array}{c}-0.450^{* * *} \\
(0.093)\end{array}$ & $\begin{array}{l}-0.338 \\
(0.206)\end{array}$ & $\begin{array}{c}-0.406^{* *} \\
(0.198)\end{array}$ & $\begin{array}{l}-0.329 \\
(0.199)\end{array}$ & $\begin{array}{c}-0.402^{* *} \\
(0.192)\end{array}$ \\
\hline RTA-HONGKONG & $\begin{array}{c}2.326^{* * *} \\
(0.129)\end{array}$ & $\begin{array}{c}-0.706^{* * *} \\
(0.097)\end{array}$ & $\begin{array}{c}-0.667^{* * *} \\
(0.083)\end{array}$ & $\begin{array}{c}-0.895^{\star * *} \\
(0.085)\end{array}$ & $\begin{array}{c}-0.839^{* * *} \\
(0.069)\end{array}$ \\
\hline RTA-MACAO & $\begin{array}{l}-0.088 \\
(0.246)\end{array}$ & $\begin{array}{c}-1.514^{* * *} \\
(0.116)\end{array}$ & $\begin{array}{c}-1.610^{* * *} \\
(0.083)\end{array}$ & $\begin{array}{c}-1.607^{* * *} \\
(0.111)\end{array}$ & $\begin{array}{c}-1.697^{* * *} \\
(0.083)\end{array}$ \\
\hline RTA-ASEAN & $\begin{array}{c}0.544^{* * *} \\
(0.087)\end{array}$ & $\begin{array}{l}-0.287^{*} \\
(0.158)\end{array}$ & $\begin{array}{l}-0.285^{\star} \\
(0.162)\end{array}$ & $\begin{array}{c}-0.372^{* *} \\
(0.150)\end{array}$ & $\begin{array}{c}-0.375^{\star *} \\
(0.156)\end{array}$ \\
\hline RTA-CHILE & 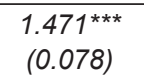 & (omitted) & $\begin{array}{c}1.848^{\star * *} \\
(0.230)\end{array}$ & (omitted) & $\begin{array}{c}1.833^{\star * *} \\
(0.226)\end{array}$ \\
\hline RTA-PAKISTAN & $\begin{array}{c}-0.194^{* *} \\
(0.091)\end{array}$ & $\begin{array}{l}-0.303 \\
(0.201)\end{array}$ & $\begin{array}{l}-0.304^{*} \\
(0.175)\end{array}$ & $\begin{array}{c}-0.410^{* *} \\
(0.194)\end{array}$ & $\begin{array}{c}-0.419^{* *} \\
(0.169)\end{array}$ \\
\hline RTA-NEWZEALAND & $\begin{array}{c}0.690^{* \star \star} \\
(0.065)\end{array}$ & $\begin{array}{c}-0.241^{* *} \\
(0.099)\end{array}$ & $\begin{array}{l}-0.170^{*} \\
(0.097)\end{array}$ & $\begin{array}{c}-0.404^{* * *} \\
(0.080)\end{array}$ & $\begin{array}{c}-0.325^{\star * *} \\
(0.073)\end{array}$ \\
\hline RTA-PERU & $\begin{array}{c}0.752^{* \star *} \\
(0.086)\end{array}$ & $\begin{array}{l}-0.088 \\
(0.077)\end{array}$ & $\begin{array}{l}-0.033 \\
(0.067)\end{array}$ & $\begin{array}{l}-0.112 \\
(0.071)\end{array}$ & $\begin{array}{l}-0.079 \\
(0.058)\end{array}$ \\
\hline RTA-COSTA RICA & $\begin{array}{c}1.591^{\star \star *} \\
(0.130)\end{array}$ & $\begin{array}{c}0.514^{\star * *} \\
(0.109)\end{array}$ & $\begin{array}{c}0.609^{* * *} \\
(0.103)\end{array}$ & $\begin{array}{c}0.550^{\star * *} \\
(0.107)\end{array}$ & $\begin{array}{c}0.642^{\star \star \star} \\
(0.101)\end{array}$ \\
\hline RTA - SWITZERLAND & $\begin{array}{c}0.894^{* * *} \\
(0.043)\end{array}$ & $\begin{array}{c}0.244^{\star * *} \\
(0.090)\end{array}$ & $\begin{array}{c}0.234^{* * *} \\
(0.086)\end{array}$ & $\begin{array}{c}0.244^{* * *} \\
(0.082)\end{array}$ & $\begin{array}{c}0.247^{\star \star *} \\
(0.073)\end{array}$ \\
\hline RTA - ICELAND & $\begin{array}{c}-1.366^{* * *} \\
(0.076)\end{array}$ & $\begin{array}{c}-0.501^{* * *} \\
(0.115)\end{array}$ & $\begin{array}{c}-0.450^{* * *} \\
(0.105)\end{array}$ & $\begin{array}{c}-0.517^{* * *} \\
(0.096)\end{array}$ & $\begin{array}{c}-0.444^{* * *} \\
(0.081)\end{array}$ \\
\hline WTO & $\begin{array}{c}0.208^{* * *} \\
(0.069)\end{array}$ & $\begin{array}{c}0.134 \\
(0.081)\end{array}$ & $\begin{array}{l}0.176^{* *} \\
(0.086)\end{array}$ & $\begin{array}{c}0.885^{* * *} \\
(0.326)\end{array}$ & $\begin{array}{c}0.929^{* * *} \\
(0.280)\end{array}$ \\
\hline Constant & $\begin{array}{c}-11.519^{* * *} \\
(0.732)\end{array}$ & $\begin{array}{c}-19.372^{* * *} \\
(2.205)\end{array}$ & $\begin{array}{c}-10.729^{* * *} \\
(2.550)\end{array}$ & $\begin{array}{c}-16.674^{* * *} \\
(1.757)\end{array}$ & $\begin{array}{c}-7.578^{* * *} \\
(2.141)\end{array}$ \\
\hline F-test ( $P$-value) & & $\begin{array}{c}62.92 \\
(0.000)\end{array}$ & & $\begin{array}{c}68.08 \\
(0.000)\end{array}$ & \\
\hline LM-test (P-value) & & & $\begin{array}{c}13056.20 \\
(0.000)\end{array}$ & & $\begin{array}{c}13523.72 \\
(0.000)\end{array}$ \\
\hline Hausman test (P-value) & & $\begin{array}{c}13.96 \\
(0.6701)\end{array}$ & & $\begin{array}{c}22.85 \\
(0.9432)\end{array}$ & \\
\hline$R^{2}$ overall & 0.824 & 0.655 & 0.805 & 0.694 & 0.804 \\
\hline$R^{2}$ within & & 0.791 & 0.789 & 0.807 & 0.806 \\
\hline$R^{2}$ between & & 0.622 & 0.805 & 0.672 & 0.802 \\
\hline Number of Observations & 2902 & 2902 & 2902 & 2902 & 2902 \\
\hline RETEST ( $p$-value) & $(0.7347)$ & $(0.0062)$ & (0.0019) & $(0.0000)$ & $(0.0003)$ \\
\hline
\end{tabular}

Notes: * significant at 10\%; ${ }^{* *}$ significant at $5 \%$; ${ }^{* * *}$ significant at $1 \%$. Robust standard errors in parentheses Source: own estimations 
MISCELLANEA GEOGRAPHICA - REGIONAL STUDIES ON DEVELOPMENT

Vol. $25 \cdot$ No. $4 \cdot 2021 \cdot$ pp. 238-245 • ISSN: 2084-6118 • DOI: 10.2478/mgrsd-2020-0064

Table 2. Dependent Variable: Total Exports

\begin{tabular}{|c|c|c|c|c|c|}
\hline Explanatory variable & $\begin{array}{l}O L S \\
\text { (1) }\end{array}$ & $\begin{array}{l}F E \\
(2)\end{array}$ & $\begin{array}{l}R E \\
(3)\end{array}$ & $\begin{array}{c}F E \text { (year) } \\
\text { (4) }\end{array}$ & $\begin{array}{c}R E \text { (year) } \\
\text { (5) }\end{array}$ \\
\hline Total GDP & $\begin{array}{c}2.337^{* * *} \\
(0.080)\end{array}$ & $\begin{array}{c}2.324^{* * *} \\
(0.248)\end{array}$ & $\begin{array}{c}2.337^{\star * *} \\
(0.226)\end{array}$ & $\begin{array}{c}1.996^{* * *} \\
(0.150)\end{array}$ & $\begin{array}{c}2.005^{\star * *} \\
(0.136)\end{array}$ \\
\hline Similarity index & $\begin{array}{c}0.920^{* \star *} \\
(0.013)\end{array}$ & $\begin{array}{c}0.833^{* * *} \\
(0.093)\end{array}$ & $\begin{array}{c}0.858^{\star * *} \\
(0.062)\end{array}$ & $\begin{array}{c}0.870^{* * *} \\
(0.090)\end{array}$ & $\begin{array}{c}0.903^{* * *} \\
(0.061)\end{array}$ \\
\hline Sum of $K / L$ ratio & $\begin{array}{l}0.081^{*} \\
(0.048)\end{array}$ & $\begin{array}{c}0.263 \\
(0.146)\end{array}$ & $\begin{array}{c}0.264 \\
(0.171)\end{array}$ & $\begin{array}{l}-0.040 \\
(0.134)\end{array}$ & $\begin{array}{l}-0.001 \\
(0.117)\end{array}$ \\
\hline Difference of $K / L$ ratio & $\begin{array}{c}0.087^{* * *} \\
(0.024)\end{array}$ & $\begin{array}{l}-0.003 \\
(0.038)\end{array}$ & $\begin{array}{l}-0.001 \\
(0.037)\end{array}$ & $\begin{array}{c}0.024 \\
(0.495)\end{array}$ & $\begin{array}{c}0.024 \\
(0.034)\end{array}$ \\
\hline Sum of $T / L$ ratio & $\begin{array}{c}-0.446^{* * *} \\
(0.053)\end{array}$ & $\begin{array}{l}-0.320 \\
(0.572)\end{array}$ & $\begin{array}{l}-0.344 \\
(0.233)\end{array}$ & $\begin{array}{l}-0.035 \\
(0.540)\end{array}$ & $\begin{array}{l}-0.271 \\
(0.223)\end{array}$ \\
\hline Difference of $T / L$ ratio & $\begin{array}{c}0.231^{* * *} \\
(0.033)\end{array}$ & $\begin{array}{c}0.123 \\
(0.144)\end{array}$ & $\begin{array}{c}0.144 \\
(0.128)\end{array}$ & $\begin{array}{c}0.112 \\
(0.132)\end{array}$ & $\begin{array}{c}0.139 \\
(0.121)\end{array}$ \\
\hline Distance & $\begin{array}{c}-0.460^{* * *} \\
(0.056)\end{array}$ & (omitted) & $\begin{array}{c}-0.664^{* * *} \\
(0.206)\end{array}$ & (omitted) & $\begin{array}{c}-0.747^{* * *} \\
(0.205)\end{array}$ \\
\hline RTA-APTA & $\begin{array}{c}-0.369^{* * *} \\
(0.086)\end{array}$ & $\begin{array}{c}-0.450^{* *} \\
(0.218)\end{array}$ & $\begin{array}{c}-0.451^{* *} \\
(0.200)\end{array}$ & $\begin{array}{c}-0.446^{* *} \\
(0.207)\end{array}$ & $\begin{array}{c}-0.449^{* *} \\
(0.190)\end{array}$ \\
\hline RTA-HONGKONG & $\begin{array}{c}2.760^{* \star *} \\
(0.127)\end{array}$ & $\begin{array}{c}-0.670^{\star * \star} \\
(0.108)\end{array}$ & $\begin{array}{c}-0.575^{\star \star *} \\
(0.084)\end{array}$ & $\begin{array}{c}-0.860^{\star \star *} \\
(0.089)\end{array}$ & $\begin{array}{c}-0.747^{\star \star * \star} \\
(0.068)\end{array}$ \\
\hline RTA-MACAO & $\begin{array}{c}0.187 \\
(0.235)\end{array}$ & $\begin{array}{c}-1.606^{\star \star *} \\
(0.118)\end{array}$ & $\begin{array}{c}-1.577^{\star \star *} \\
(0.078)\end{array}$ & $\begin{array}{c}-1.706^{* * *} \\
(0.113)\end{array}$ & 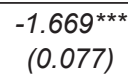 \\
\hline RTA-ASEAN & $\begin{array}{c}0.418^{* * *} \\
(0.087)\end{array}$ & $\begin{array}{l}-0.306 \\
(0.186)\end{array}$ & $\begin{array}{l}-0.291 \\
(0.179)\end{array}$ & $\begin{array}{c}-0.410^{* *} \\
(0.175)\end{array}$ & $\begin{array}{c}-0.389^{* *} \\
(0.170)\end{array}$ \\
\hline RTA-CHILE & $\begin{array}{c}1.052^{* * *} \\
(0.078)\end{array}$ & (omitted) & $\begin{array}{c}1.221^{\star * \star} \\
(0.227)\end{array}$ & (omitted) & $\begin{array}{c}1.216^{* * *} \\
(0.230)\end{array}$ \\
\hline RTA-PAKISTAN & $\begin{array}{l}-0.008 \\
(0.092)\end{array}$ & $\begin{array}{l}-0.221 \\
(0.217)\end{array}$ & $\begin{array}{l}-0.191 \\
(0.195)\end{array}$ & $\begin{array}{l}-0.347^{*} \\
(0.204)\end{array}$ & $\begin{array}{l}-0.318^{*} \\
(0.188)\end{array}$ \\
\hline RTA-NEWZEALAND & $\begin{array}{c}0.520^{* * *} \\
(0.057)\end{array}$ & $\begin{array}{c}-0.281^{* * *} \\
(0.093)\end{array}$ & $\begin{array}{c}-0.262^{* * *} \\
(0.093)\end{array}$ & $\begin{array}{c}-0.440^{* * *} \\
(0.073)\end{array}$ & $\begin{array}{c}-0.407^{* * *} \\
(0.069)\end{array}$ \\
\hline RTA-PERU & $\begin{array}{c}0.426^{* * *} \\
(0.067)\end{array}$ & $\begin{array}{c}0.363^{* * *} \\
(0.067)\end{array}$ & $\begin{array}{c}0.361^{* * *} \\
(0.061)\end{array}$ & $\begin{array}{c}0.374^{* * *} \\
(0.066)\end{array}$ & $\begin{array}{c}0.356^{\star * *} \\
(0.056)\end{array}$ \\
\hline RTA-COSTA RICA & $\begin{array}{l}0.215^{*} \\
(0.121)\end{array}$ & $\begin{array}{l}-0.154^{*} \\
(0.093)\end{array}$ & $\begin{array}{l}-0.128 \\
(0.090)\end{array}$ & $\begin{array}{l}-0.080 \\
(0.091)\end{array}$ & $\begin{array}{l}-0.600 \\
(0.087)\end{array}$ \\
\hline RTA - SWITZERLAND & $\begin{array}{c}-1.310^{* \star *} \\
(0.045)\end{array}$ & $\begin{array}{c}-1.088^{\star \star \star} \\
(0.095)\end{array}$ & $\begin{array}{c}-1.101^{* * *} \\
(0.087)\end{array}$ & $\begin{array}{c}-1.057^{* \star *} \\
(0.081)\end{array}$ & $\begin{array}{c}-1.048^{* \star \star} \\
(0.072)\end{array}$ \\
\hline RTA - ICELAND & $\begin{array}{c}-0.776^{* * *} \\
(0.077) \\
\end{array}$ & $\begin{array}{c}-0.255^{\star *} \\
(0.101)\end{array}$ & $\begin{array}{c}-0.253^{\star * *} \\
(0.094) \\
\end{array}$ & $\begin{array}{c}-0.237^{\star \star *} \\
(0.082)\end{array}$ & $\begin{array}{c}-0.206^{* * *} \\
(0.070)\end{array}$ \\
\hline WTO & $\begin{array}{l}0.205^{\star *} \\
(0.080)\end{array}$ & $\begin{array}{l}0.136^{*} \\
(0.080)\end{array}$ & $\begin{array}{l}0.140^{*} \\
(0.082)\end{array}$ & $\begin{array}{c}0.940^{\star * *} \\
(0.278)\end{array}$ & $\begin{array}{c}0.853^{\star * \star} \\
(0.238)\end{array}$ \\
\hline Constant & $\begin{array}{c}-13.999^{* \star *} \\
(0.732)\end{array}$ & $\begin{array}{c}-18.176^{\star * \star} \\
(2.125)\end{array}$ & $\begin{array}{c}-12.221^{* * *} \\
(2.611)\end{array}$ & $\begin{array}{c}-15.355^{\star * *} \\
(1.652)\end{array}$ & $\begin{array}{c}-7.578^{* * *} \\
(2.141)\end{array}$ \\
\hline F-test (P-value) & & $\begin{array}{c}68.43 \\
(0.0000)\end{array}$ & & $\begin{array}{c}74.81 \\
(0.0000)\end{array}$ & \\
\hline LM-test (P-value) & & & $\begin{array}{c}14333.58 \\
(0.000)\end{array}$ & & $\begin{array}{c}14892.82 \\
(0.000)\end{array}$ \\
\hline Hausman test (P-value) & & & $\begin{array}{c}42.95 \\
(0.0005)\end{array}$ & & $\begin{array}{c}54.93 \\
(0.0172)\end{array}$ \\
\hline$R^{2}$ overall & 0.824 & 0.7843 & 0.8053 & 0.7604 & 0.8056 \\
\hline$R^{2}$ within & & 0.8110 & 0.8109 & 0.8280 & 0.8277 \\
\hline$R^{2}$ between & & 0.7770 & 0.7995 & 0.7460 & 0.7968 \\
\hline Number of Observations & 2902 & 2926 & 2926 & 2926 & 2926 \\
\hline RETEST ( $p$-value) & $(0.1890)$ & $(0.0182)$ & $(0.0204)$ & $(0.0283)$ & $(0.0003)$ \\
\hline
\end{tabular}

Notes: * significant at 10\%; ${ }^{* *}$ significant at 5\%; ${ }^{* * *}$ significant at 1\%. Robust standard errors in parentheses

Source: own estimations 
Table 3. Dependent Variable: Total Imports

\begin{tabular}{|c|c|c|c|c|c|}
\hline Explanatory variable & $\begin{array}{l}\text { OLS } \\
\text { (1) }\end{array}$ & $\begin{array}{l}F E \\
\text { (2) }\end{array}$ & $\begin{array}{l}R E \\
\text { (3) }\end{array}$ & $\begin{array}{c}\text { FE (year) } \\
\text { (4) }\end{array}$ & $\begin{array}{l}R E \text { (year) } \\
\text { (5) }\end{array}$ \\
\hline Total GDP & $\begin{array}{c}2.590^{\star \star *} \\
(0.097)\end{array}$ & $\begin{array}{c}2.115^{\star * \star} \\
(0.230)\end{array}$ & $\begin{array}{c}2.425^{\star * *} \\
(0.263)\end{array}$ & $\begin{array}{l}1.910^{\star * *} \\
(0.186)\end{array}$ & $\begin{array}{c}2.093^{* * *} \\
(0.200)\end{array}$ \\
\hline Similarity index & $\begin{array}{l}1.395^{\star \star *} \\
(0.028)\end{array}$ & $\begin{array}{l}0.559^{* \star *} \\
(0.203)\end{array}$ & $\begin{array}{l}1.094^{* * *} \\
(0.122)\end{array}$ & $\begin{array}{c}0.565^{\star \star \star} \\
(0.197)\end{array}$ & $\begin{array}{l}1.181^{* * *} \\
(0.112)\end{array}$ \\
\hline Sum of $K / L$ ratio & $\begin{array}{l}0.159^{*} \\
(0.061)\end{array}$ & $\begin{array}{c}0.199 \\
(0.334)\end{array}$ & $\begin{array}{l}0.642^{* *} \\
(0.254)\end{array}$ & $\begin{array}{l}-0.040 \\
(0.385)\end{array}$ & $\begin{array}{c}0.402 \\
(0.258)\end{array}$ \\
\hline Difference of $K / L$ ratio & $\begin{array}{l}0.253^{* * *} \\
(0.046)\end{array}$ & $\begin{array}{l}-0.061 \\
(0.069)\end{array}$ & $\begin{array}{l}-0.013 \\
(0.073)\end{array}$ & $\begin{array}{l}-0.039 \\
(0.072)\end{array}$ & $\begin{array}{c}0.021 \\
(0.073)\end{array}$ \\
\hline Sum of $T / L$ ratio & $\begin{array}{c}0.047 \\
(0.591)\end{array}$ & $\begin{array}{l}-1.716^{*} \\
(0.984)\end{array}$ & $\begin{array}{c}0.390 \\
(0.244)\end{array}$ & $\begin{array}{l}-1.689^{*} \\
(1.012)\end{array}$ & $\begin{array}{l}0.421^{*} \\
(0.248)\end{array}$ \\
\hline Difference of $T / L$ ratio & $\begin{array}{l}0.356^{* \star *} \\
(0.054)\end{array}$ & $\begin{array}{l}-0.118 \\
(0.191)\end{array}$ & $\begin{array}{l}-0.139 \\
(0.147)\end{array}$ & $\begin{array}{l}-0.121 \\
(0.197)\end{array}$ & $\begin{array}{l}-0.025 \\
(0.147)\end{array}$ \\
\hline Distance & $\begin{array}{c}-0.943^{* * *} \\
(0.090)\end{array}$ & (omitted) & $\begin{array}{c}-1.326^{* * *} \\
(0.333)\end{array}$ & (omitted) & $\begin{array}{c}-1.338^{\star \star *} \\
(0.328)\end{array}$ \\
\hline RTA-APTA & $\begin{array}{c}-0.980^{* * *} \\
(0.159)\end{array}$ & $\begin{array}{l}-0.364^{*} \\
(0.205)\end{array}$ & $\begin{array}{l}-0.600^{* *} \\
(0.240)\end{array}$ & $\begin{array}{l}-0.382^{*} \\
(0.214)\end{array}$ & $\begin{array}{l}-0.654^{* *} \\
(0.263)\end{array}$ \\
\hline RTA-HONGKONG & $\begin{array}{l}0.624^{* *} \\
(0.247)\end{array}$ & $\begin{array}{c}-1.759^{* * *} \\
(0.141)\end{array}$ & $\begin{array}{c}-1.827^{* * *} \\
(0.132)\end{array}$ & $\begin{array}{c}-1.912^{* * *} \\
(0.158)\end{array}$ & $\begin{array}{c}-1.967^{* * *} \\
(0.140)\end{array}$ \\
\hline RTA-MACAO & $\begin{array}{l}-0.481 \\
(0.377)\end{array}$ & $\begin{array}{c}-1.925^{* * *} \\
(0.227)\end{array}$ & $\begin{array}{c}-2.459^{* * *} \\
(0.135)\end{array}$ & $\begin{array}{c}-1.998^{* * *} \\
(0.231)\end{array}$ & $\begin{array}{c}-2.551^{* * *} \\
(0.145)\end{array}$ \\
\hline RTA-ASEAN & $\begin{array}{c}1.060^{* * *} \\
(0.128)\end{array}$ & $\begin{array}{l}-0.301 \\
(0.376) \\
\end{array}$ & $\begin{array}{l}-0.293 \\
(0.390) \\
\end{array}$ & $\begin{array}{l}-0.333 \\
(0.150) \\
\end{array}$ & $\begin{array}{l}-0.375 \\
(0.156)\end{array}$ \\
\hline RTA-CHILE & $\begin{array}{c}2.438^{* * *} \\
(0.114)\end{array}$ & (omitted) & $\begin{array}{l}3.221^{* * *} \\
(0.377)\end{array}$ & (omitted) & $\begin{array}{l}3.062^{* * *} \\
(0.361)\end{array}$ \\
\hline RTA-PAKISTAN & $\begin{array}{c}-0.470^{* * *} \\
(0.176)\end{array}$ & $\begin{array}{c}-1.449^{* \star *} \\
(0.290)\end{array}$ & $\begin{array}{c}-1.214^{\star * *} \\
(0.250)\end{array}$ & $\begin{array}{c}-1.498^{* \star \star} \\
(0.297)\end{array}$ & $\begin{array}{c}-1.280^{* * *} \\
(0.253)\end{array}$ \\
\hline RTA-NEWZEALAND & $\begin{array}{c}1.448^{* * *} \\
11111(0.124)\end{array}$ & $\begin{array}{c}-0.430^{* * *} \\
(0.149)\end{array}$ & $\begin{array}{l}-0.162 \\
(0.129)\end{array}$ & $\begin{array}{c}-0.544^{* \star *} \\
(0.165)\end{array}$ & $\begin{array}{l}-0.263^{* *} \\
(0.126)\end{array}$ \\
\hline RTA-PERU & $\begin{array}{l}1.848^{* \star \star} \\
(0.146)\end{array}$ & $\begin{array}{c}-0.530^{\star * *} \\
(0.144)\end{array}$ & $\begin{array}{c}-0.378^{\star * \star} \\
(0.114)\end{array}$ & $\begin{array}{c}-0.618^{* * *} \\
(0.137)\end{array}$ & $\begin{array}{c}-0.485^{\star \star *} \\
(0.110)\end{array}$ \\
\hline RTA-COSTA RICA & $\begin{array}{c}4.386^{\star \star \star} \\
(0.251)\end{array}$ & $\begin{array}{l}0.796^{* \star *} \\
(0.220)\end{array}$ & $\begin{array}{l}1.337^{* * *} \\
(0.209)\end{array}$ & $\begin{array}{l}0.737^{* \star *} \\
(0.221)\end{array}$ & $\begin{array}{l}1.348^{* * *} \\
(0.206)\end{array}$ \\
\hline RTA - SWITZERLAND & $\begin{array}{l}2.251^{* * *} \\
(0.080)\end{array}$ & $\begin{array}{c}0.478^{* \star \star} \\
(0.122)\end{array}$ & $\begin{array}{c}0.394^{* * *} \\
(0.120)\end{array}$ & $\begin{array}{c}0.527^{\star * *} \\
(0.147)\end{array}$ & $\begin{array}{c}0.422^{* * *} \\
(0.127)\end{array}$ \\
\hline RTA - ICELAND & $\begin{array}{c}-1.097^{* \star *} \\
(0.144)\end{array}$ & 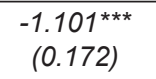 & $\begin{array}{c}-0.802^{* * *} \\
(0.136)\end{array}$ & $\begin{array}{c}-1.081^{* * *} \\
(0.192)\end{array}$ & $\begin{array}{c}-0.757^{* * *} \\
(0.139)\end{array}$ \\
\hline WTO & $\begin{array}{c}0.481^{\star \star \star} \\
(0.126)\end{array}$ & $\begin{array}{c}0.165 \\
(0.132)\end{array}$ & $\begin{array}{l}0.342^{* *} \\
(0.144)\end{array}$ & $\begin{array}{c}0.284 \\
(0.540)\end{array}$ & $\begin{array}{l}0.867^{* *} \\
(0.425)\end{array}$ \\
\hline Constant & $\begin{array}{c}-9.158^{* * *} \\
(1.166)\end{array}$ & $\begin{array}{c}-24.027^{* * *} \\
(3.915)\end{array}$ & $\begin{array}{l}-5.563 \\
(3.861)\end{array}$ & $\begin{array}{c}-22.489^{* * *} \\
(3.765)\end{array}$ & $\begin{array}{c}-2.584^{\star * *} \\
(2.141)\end{array}$ \\
\hline F-test (P-value) & & $\begin{array}{c}25.30 \\
(0.0000)\end{array}$ & & $\begin{array}{c}25.50 \\
(0.0000)\end{array}$ & \\
\hline LM-test (P-value) & & & $\begin{array}{l}5904.34 \\
(0.0000)\end{array}$ & & $6083.48(0.000)$ \\
\hline Hausman test ( $P$-value) & & & & $\begin{array}{c}119.57 \\
(0.0000)\end{array}$ & \\
\hline$R^{2}$ overall & 0.7135 & 0.1801 & 0.6844 & 0.1675 & 0.6932 \\
\hline$R^{2}$ within & & 0.4320 & 0.4164 & 0.4443 & 0.4270 \\
\hline$R^{2}$ between & & 0.1238 & 0.7580 & 0.1089 & 0.7695 \\
\hline Number of Observations & 2841 & 2841 & 2841 & 2841 & 2841 \\
\hline RETEST (p-value) & $(0.0000)$ & $(0.6031)$ & $(0.0226)$ & $(0.4223)$ & $(0.0101)$ \\
\hline
\end{tabular}

Notes: * significant at 10\%; ${ }^{* *}$ significant at $5 \%$; ${ }^{* * *}$ significant at $1 \%$. Robust standard errors in parentheses Source: own estimations 
Costa Rica and Switzerland are positively related to China's trade volume. As before, the Hausman test with p-value 0.943 favours the use of the random effects estimator over the fixed effects estimator

Following the previous empirical studies discussed in the literature review section, the effects of preferential trade liberalization might be different for China's exports and imports. Therefore, estimating these effects is done separately for exports and imports. Table 2 shows the estimation results of the effectiveness of China's trade liberalization on its bilateral exports, while Table 3 presents the effectiveness on its bilateral imports. Each column in Tables 2 and 3 is a direct counterpart of the columns in Table 1.

The estimation results reported in Tables 2 and 3 show that the majority of our previous conclusions for the volume of trade hold also for exports and imports. However, there are also some important differences. For example, the trade agreement with Peru that was not significant in the case of total trade seems to have a positive effect on China's exports. At the same time, the agreements with Costa Rica and Switzerland that were positive and significant in the case of total trade are now positive and statistically significant only in the case of imports.

Hence, it can be concluded that the trade agreements with Switzerland and Costa Rica which led to expansion of China's bilateral trade are driven by its significant impact on China's import volume. While the expansion of bilateral trade volume led by the trade agreement with Chile is due to its positive effect on both the exports and imports of China. Similarly, the positive effect of China's accession to the WTO for volume of trade was driven by both exports and imports.

\section{Conclusions}

The main goal of this paper was to investigate empirically the effectiveness of China's foreign trade liberalization using an augmented gravity equation estimated for a panel of 175 of China's trading partners during the period 1995-2016. The estimation results confirmed the main research hypothesis on the effectiveness of institutionalized liberalization. This is evidenced by the positive and statistically-significant estimates of the indicator variable for WTO membership. China's accession to the WTO was revealed to have had significant effects on both exports and imports. At the same time, the results obtained for the regional and bilateral free trade agreements yielded mixed results. The majority of regional and bilateral trade agreements were found not to be effective in increasing China's foreign trade. Only the agreements with Chile, Costa Rica and Switzerland were found to be effective in increasing China's trade volume. Moreover, the results for Chile were driven by increases in both exports and imports while, for Costa Rica and Switzerland, by increased imports from these countries. Therefore, the assembled empirical evidence confirms the lack of clear theoretical guidance on the effectiveness of regional and bilateral trade agreements, as the estimates of the parameters accompanying the variable vary according to the country with which these agreements were concluded and are characterized by different levels of statistical significance. These results support the view, expressed in previous studies, that the majority of China's trade agreements were of low quality in terms of coverage and liberalization because they were driven largely by political, and not economic considerations. Therefore, the main policy implication for other countries is that one effective form of trade liberalization is institutionalized liberalization in the form of unilateral accession to a pre-existing international organization. However, these results need to be treated with caution as some trade agreements imply a gradual trade liberalization whose effects might become visible only after several years. Therefore, the effects of such agreements should be re-evaluated in future studies.

ORCID

Andrzej Cieślik (1) https://orcid.org/0000-0002-7834-7384

\section{References}

Antkiewicz, A \& Whalley, J 2011, 'China's new regional trade agreements' in China's integration into the world economy, ed. J Whalley, World Scientific, Singapore, pp. 99-121.

Bagwell, K \& Staiger, RW 1998, 'Will preferential agreements undermine the multilateral trading system?', Economic Journal, vol. 108, no. 449, pp. 1162-1182.

Baldwin, R, Forslid, R, Martin, P, Ottaviano, G \& Robert-Nicoud, F 2003, 'Economic geography and public policy', Princeton University Press, Princeton.

Bhagwati, J, Greenaway, D \& Panagariya, A 1998, 'Trading preferentially: Theory and policy', Economic Journal, vol.108, no. 449, pp. 1128-1148.

Bhattacharya, S \& Bhattacharyay, B 2007, 'Gains and losses of India-China trade cooperation - A gravity model impact analysis', CESifo working paper series, no. 1970.

Cieślik, A 2007, 'The impact of free trade agreements on Poland's foreign trade in 1992-2004', Bank \& Credit, vol. 38, no. 6 , pp. 3-23.

Cieślik, A 2009, 'Bilateral trade volumes, the gravity equation and factor proportions', Journal of International Trade \& Economic Development, vol. 18, no. 1, pp. 37-59.

Cieślik, A 2015, 'Augmented gravity equation and incomplete specialization in production', International Economics Letters, vol. 4, no. 1, pp. 26-34

Cieślik, A \& Hagemejer, J 2009, 'Assessing the impact of the EU-sponsored trade liberalization in the MENA countries', Journal of Economic Integration, vol. 24, no. 2, pp. 344-369.

Cieślik, A \& Hagemejer, J 2011, 'Evaluating the effectiveness of preferential trade liberalization in Central and Eastern
Europe', International Trade Journal, vol. 25, no. 5, pp. 516-538.

Cieślik, A, Michałek, JJ \& Mycielski, J 2009, 'Forecast of trade effects of joining the European Monetary Union for Poland under a generalized gravity model', Bank \& Credit, vol. 40, no. 1 , pp. $69-88$.

Cieślik, A, Michałek, JJ \& Mycielski, J 2012, 'Measuring the trade effects of the euro in Central and Eastern Europe', Journal of International Trade \& Economic Development, vol. 21, no. 1, pp. 25-49.

Cieślik, A, Michałek, JJ \& Mycielski, J 2014, 'Trade effects of the euro adoption by the EU new member states', Bank \& Credit, vol. 45, no. 4, pp. 331-348.

Cieślik, A \& Song, T 2012, 'Is a regional trading bloc forming in southeast Asia? New evidence for ASEAN countries', Miscellanea Geographica - Regional Studies on Development, vol. 16, no. 2, pp. 23-29.

Dembatapitiya, P \& Weerahewa, J 2015, 'Effects of regional trading agreements on South Asian trade: A gravity model analysis', Tropical Agricultural Research, vol. 26, no. 3, pp. 468-485.

Devadason, ES 2015, 'Framing China-Malaysia trade relations beyond ASEAN: Factoring the regional comprehensive economic partnership', Journal of Developing Areas, vol. 49 , no. 2, pp. 39-56.

Devadason, ES, Baharumshah, AZ \& Subramaniam, T 2014, 'Leveraging trade opportunities with non-traditional partners: the Malaysia-GCC perspective', Pacific Review, vol. 27, no. 1, pp. 97-122. 
Devadason, ES, Chandran, VGR \& Mubarik, SM 2017, 'Sino-LAC Ties: Trade relationships, trade potentials, and asymmetric dependency', Emerging Markets Finance and Trade, vol. 53, no. 6 , pp. $1262-1277$.

Devadason, ES, \& Mubarik, SM 2021, 'Intraregional export flows and export efficiency in Palm Oil and Palm-Based Products: Southeast Asia and Latin America regions compared', The International Trade Journal, DOI: 10.1080/08853908.2021.1897960.

Ekanayake, EM, Mukherjee, A \& Veeramacheneni, B 2010, 'Trade blocks and the gravity model: A study of economic integration among Asian developing countries', Journal of Economic Integration, vol. 25, no. 4, pp. 627-643.

Ethier, WJ 1998, 'The new regionalism', Economic Journal, vol. 108, no. 449, pp. 1149-1161.

Grossman, GM \& Helpman, E 1994, 'Protection for sale', American Economic Review, vol. 84, no. 4, pp. 833-850.

Grossman, GM \& Helpman, E 1995, 'Trade wars and trade talks', Journal of Political Economy, vol. 103, no. 4, pp. 675-708.

lanchovichina, E \& Martin, W 2004, 'Impacts of China's accession to the World Trade Organization', World Bank Economic Review, vol. 18, no. 1, pp. 3-27.

Kwei, ES 2013, 'Chinese trade bilateralism: Politics still in command' in Bilateral trade agreements in the Asia-Pacific, eds $\vee$ Aggarwal \& S Urata, Routledge, Abingdon, pp. 133155.

Li, C, Wang, J \& Whalley, J 2017, 'China's regional and bilateral trade agreements' in The economies of China and India cooperation and conflict: Volume 1: China and India-The International Context and Economic Growth, Manufacturing Performance and Rural Development, World Scientific, Singapore, pp. 175-194.

Panagariya, A 2000, 'Preferential trade liberalization: The traditional theory and new developments', Journal of Economic Literature, vol. 38, no. 2, pp. 287-331.

Park, D, Park, I \& Estrada, GEB 2008, 'Prospects of an ASEANPeople's Republic of China Free Trade Area: A qualitative and quantitative analysis', Asian Development Bank Economics Working Paper Series, vol. 130.

Ravenhill, J 2010, 'The 'new East Asian regionalism': A political domino effect', Review of International Political Economy, vol. 17, no. 2, pp. 178-208.

Rivera-Batiz, LA \& Oliva, MA 2003, International trade. Theory, strategies and evidence, Oxford University Press, Oxford.

Rose, AK 2004, 'Do we really know that the WTO increases trade?', American Economic Review, vol. 94, no. 1, pp. 98-114.

Sampson, M 2021, 'The evolution of China's regional trade agreements: power dynamics and the future of the AsiaPacific', The Pacific Review, vol. 34, no. 2, pp. 259-289.

Song, G, \& Yuan, WJ 2012, 'China's free trade agreement strategies'. The Washington Quarterly, vol. 35, no. 4, pp. 107-119.

Song, T \& Cieślik, A 2020, 'The effects of free trade agreements on regional wages in China', Economic Systems, vol. 44, no. 3, pp. $100-772$.

Sheng, Y, Tang, HC \& Xu, X 2012, 'The impact of ACFTA on People's Republic of China-ASEAN trade: Estimates based on an extended gravity model for component trade', $A D B$ Working Paper Series on Regional Economic Integration, no. 99.

Subramanian, A \& Wei, SJ 2007, 'The WTO promotes trade, strongly but unevenly' Journal of International Economics, vol. 72 , no. 1, pp. 151-175.
Tomz, M, Goldstein, JL \& Rivers, D 2007, 'Do we know that the WTO increase trade? Comment', American Economic Review, vol. 97, no. 5, pp. 2005-2018.

Zeng, K 2010, 'Multilateral versus bilateral and regional trade liberalization: Explaining China's pursuit of free trade agreements (FTAs)', Journal of Contemporary China, vol. 19 , no. 66 , pp. 635-652.

Zeng, K 2016, 'China's free trade agreement diplomacy', The Chinese Journal of International Politics, vol. 9, no. 3, pp. 277-305. 